narrow vertical strip of black sheet-metal or cardboard is fixed across the mouth of the telescope with plasticine, and the telescope is adjusted until the bright image of the slit is completely obstructed. On looking past the strip towards the prisms the observer will see parts of the latter brilliantly lit. By slightly shifting each prism in turn and watching for movement in the bright specks, those due to each prism are readily identified. H. HARTRIDGE.

King's College, Cambridge.

\section{Land Snails of the Madeira Islands.}

IN $r 892$ (Journal of Conchology, vol. vii. No. I) the Rev. R. Boog Watson published a very interesting discussion of the Madeira snails, in which he raised many questions concerning their origin and history, which he did not attempt to answer. To-day, we are still groping for light, but I believe we may reach a number of conclusions which are not likely to prove erroneous.

(I.) It is not true that the numerous endemic snails of the islands have come " without trace of descent." They are quite clearly of Palæarctic origin, and their ancestors may be looked for in the rocks of Europe. Among the European Tertiary fossils, Plebecula ramondi Brong., from the Miocene of Germany, resembles the Madeira and Porto Santo Pleistocene fossil P. bowditchiana; Pseudocampylaea insignis Klein, from the Miocene of Würtemberg, resembles the great $P$. lowei of Porto Santo, but is not so large; two species of Craspedopoma, apparently allied to Madeira forms, are found in the Eocene of France. These fossils may be seen in the British Museum. In the absence of anatomical evidence, the relationships of these fossils must remain somewhat uncertain, but it is at least probable that their apparent affinity with the Madeira snails is not wholly deceptive.

(2.) Considering the diversity and strong peculiarities of most of the Madeira species, it is unlikely that their ancestors arrived later than the beginning of the Tertiary, and it is not improbable that at least part of the immigration dates from the Upper Cretaceous. This postulates a greater age for the islands than our present geological information can confirm. According to this view, the European fossils are presumably not the actual ancestors of the Madeira fauna, but derivatives from the same general stock.

(3.) A comparison between the snails of Madeira and the adjacent island of Porto Santo, which is easily visible from the coast of the larger island, shows that we have two very distinct faunæ, with very few species in common. More than this, various genera or subgenera are restricted to one of these islands, or specially characteristic of one. It is, I think, quite certain that during the whole long history of the snail fauna, Madeira and Porto Santo were never united. On the other hand, everything indicates that the three Desertas were during Tertiary time joined together and continuous, or nearly continuous, with Madeira. The following facts are illustrative :

Pseudocampylæa. Two species, Porto Santo only. Cryptaxis. Three species, Madeira and Desertas (Leptaxis differs anatomically, as I shall show elsewhere).

Katostoma. Several forms, Porto Santo and adjacent islets.

Lampadia. One species, Porto Santo.

Madeiran membranacea does not belong here.)

Idiomela. One species, Porto Santo.

Hispidella. One species, Madeira.

Lemniscia. One species, Porto Santo. (I am satisfied that the Madeira calva and galeata are not related.)

Actinella. Five species, Madeira and Desertas.

Hystricella. Seven species, Porto Santo and adjacent islets.

Geomitra. Seven species, Madeira and Desertas.

This list could be extended, but it is, I think, sufficient to indicate, not only that Madeira and Porto Santo were not united, but that they were never united with the mainland. The diversity of the genera and subgenera on the two islands might be expected as the result of accidental colonisation at very rare intervals, but could scarcely result from the breaking up of an originally homogeneous fauna. If we employ the aggregate genera Leptaxis and Geomitra (properly Ochthephila Beck, which is not preoccupied) without subdivision, the actual facts are obscured.

(4.) Nevertheless, we have to account for the occurrence of a certain number of identical species in the two islands, and the fact that some of the groups, such as D.scula, are well represented on both islands, with closely allied species. The identical species were not introduced by man, as they occur fossil in the Pleistocene of Caniçal. As a general rule, when a group has representatives on both islands, it appears to be primarily or primitively a Porto Santo group. An apparent exception is Callina, with four Madeira species and one (rotula) in Porto Santo. The species rotula is very peculiar, and probably should not be associated with the others. How these various snails or their ancestors crossed the 23 miles from one island to the other is unknown. Some may have been carried by birds, possibly some may have come on floating pumice or other floating objects. ${ }^{1}$ The reason for the apparent tendency of Porto Santo types to reach Madeira, rather than the reverse, may be found in the fact that the arid eastern end of Madeira is well suited to Porto Santo species, while Porto Santo is unsuited to the species from the moister uplands or coasts of the greater part of Madeira.

(5) The occurrence of well-defined species and subspecies on the islets around Porto Santo-some of them no larger than a large building-proves that no important oscillations of level have taken place in recent geological time. Very moderate alterations of level would submerge the islets, or unite them with the main island. The existence of these distinct forms on islets close to the main island also proves that the means of crossing the sea, whatever they are, operate at extremely infrequent intervals.

(6.) With regard to the species of the Madeiras which are actually identical with those of Europe, it must be said that the presumption is in nearly every case that they were introduced by man. It is possible, however, that some of the smaller ones were brought by "natural" means in geologically recent times, and highly probable that Bulea was so brought to Porto Santo, on the feet of birds. Records of the occurrence of European species in the Pleistocene deposits of Madeira and Porto Santo all break down on critical examination.

That the islands are really "oceanic " is indicated by the total absence of indigenous mammals (except bats) and amphibians, and the general character of the invertebrate fauna and of the flora. The multitude of snails has seemed to suggest a former land connection, but I now believe that the snails themselves negative this view. T. D. A. COCKERELL.

University of Colorado, Boulder, March 2.

1 Experiments should be made to determine whether it is even possible for snails protected by epiphragm or operculum, to pais alive through the alimentary canal of birds. Compare Wallis Kew, "The Dispersal of Shells," p. 45 . 